\title{
Postfoundational practical theology as public Christology
}

\author{
Author: \\ Johann-Albrecht Meylahn ${ }^{1}$ \\ Affiliation: \\ ${ }^{1}$ Department of Practical \\ Theology, University of \\ Pretoria, South Africa \\ Correspondence to: \\ Johann-Albrecht Meylahn \\ Email: \\ jmeylahn@lantic.net \\ Postal address: \\ PO Box 14885, Lyttelton \\ 0140, South Africa \\ Dates: \\ Received: 03 June 2013 \\ Accepted: 20 Aug. 2013 \\ Published: 06 Aug. 2014 \\ How to cite this article: \\ Meylahn, J.A., 2014, \\ 'Postfoundational practical \\ theology as public \\ Christołogy', Verbum et \\ Ecclesia 35(2), Art. \#875, \\ 11 pages. http://dx.doi. \\ org/10.4102/ve.v35i2.875

\section{Copyright:} \\ (C) 2014. The Authors. \\ Licensee: AOSIS \\ OpenJournals. This work \\ is licensed under the \\ Creative Commons \\ Attribution License.
}

Read online:

口is Scan this QR Scan this $Q R$ code with your smart phone or mobile device to read online.
This article aimed to provide a critical appreciation of a postfoundational practical theology as developed by Julian Müller and a further exploration of this approach towards a public Christolegy. The logos of Christology is crossed out, but not erased as it is not a new theory or system or dogma, but rather a spirituality. Such a public Christology was unpacked as a postmetaphysical reformed spirituality in the three publics of academia, society and church.

\section{Introduction}

\section{The shifts in practical theology}

Practical theology traditionally had the task of bringing into normative or transformative conversation, Christian tradition and cultural-religious experiences and practices, or Text and context, and over the years of practical theological theory and/or methodology various models for this conversation have been developed. At first it was a rather linear conversation where historic theology discovered the truths and systematic theology captured that truth into coherent dogmatic statements which could then be applied to the context of practice. Louw (2011:1) argues that this historic phase of practical theological thinking was dominated 'by the agenda of orthodox thinking: right and true doctrine'. The linguistic turn in philosophy, and by implication in the humanities, brought about a new understanding of theology and particularly of practical theology.

In response to the role that the cultural-social context plays in our thinking, Paul Tillich (1951:36) developed the correlational approach, which understood theology as a correlation between the existential questions emerging from cultural experiences and answers from the Christian Scriptures. David Tracy (1975:43-63) further developed Tillich's correlational approach into what he termed the critical correlational approach. Tracy emphasised a mutually critical correlation between Scripture and the context of culturally embedded experiences. Thus, with the linguistic turn, cultural experience and tradition, or theory and practice, or normative Text and context, can no longer be seen as separated, but these previous opposites are understood to be mutually dependent, therefore influencing each other. After the linguistic turn, practical theology could no longer be seen as this linear approach of applied theology. A circular and spiral approach emerged, as theories are practice laden and practices are theory laden (see Browning 1991). With this turn, practical theology, which has as its focus this conversation between what can broadly be termed Text and context, moved from the margins of theology to the centre, as the hermeneutic reflection and conversation became the 'essence' of theology. Because of this hermeneutical task of practical theology, Browning could boldly proclaim that practical theology is fundamental practical theology. According to fundamental practical theology, the hermeneutic task of practical theology is the fundamental task of theology as such.

Another shift took place and that is the shift out of the church and into the public sphere. Previously, practical theology focused on practices within the church according to the various sub-disciplines of practical theology and Louw (2011) refers to this as the homiletic paradigm and ecclesial paradigm. The ecclesial or homiletic paradigm followed the linear approach of aligning the practices of the church to the dogmatic statements. After the linguistic turn, practical theology no longer focuses exclusively on the practices of the church, but investigates religious dimensions of various human practices. This shift has been described by some as a shift towards lived religion (Failing \& Heimbrock 1998; Gräb 2002; Ganzevoort 2009). The shift to the hermeneutic understanding of theology, as well as the shift in focus to lived religion, emphasises the need for interdisciplinary conversations within practical theology (see Ganzevoort 2009). It is in the context of the linguistic turn, as well as the growing importance for interdisciplinary conversations, that Julian Müller's $(2004,2011)$ postfoundational approach to practical theology offers important insights. 


\section{Müller's postfoundational practical theology}

Müller's postfoundational approach begins with the context of experience and practice (church practices and experiences, as well as lived religion). It begins in the context of theoryladen practices and these practices need to be understood and interpreted and thus the first three movements of his approach focus on describing and interpreting these theoryladen practices through interdisciplinary conversations (Müller 2004:300). As such, the first three movements are:

- A specific context is described.

- In-context experiences are listened to and described.

- Interpretation of experiences is made, described and developed in collaboration with 'co-researchers'.

The focus is on existential experiences within a specific context. The fourth movement in Müller's approach focuses on the traditions of interpretation and how these traditions inform the description of experiences. Description of experiences is never undertaken in a vacuum, but it is part of a social construct and thus there are numerous traditions that partake in the construction of that particular local context. These traditions inform how the experiences within that context are experienced, described and therefore how they are interpreted. The postfoundational approach, which developed from the transversal rationality of Welsch and Schrag (see Van Huyssteen 1997, 1998), understands that no tradition is foundational and that understanding and interpretation happens in the transversal space where traditions interweave and intersect. The various traditions that inform and shape a context are brought into consideration and therefore the importance of interdisciplinary conversations.

In the fifth movement, the focus is on the presence of God, namely a reflection on God's presence as it is understood and experienced in a specific situation (Müller 2004:300). God's presence is understood within the context of the metaphors and narrative resources of that particular community's reflections about the divine or sacred. God's presence can be interpreted or reflected upon within the context of that particular community, that is, as part and parcel of that particular social construction.

Does the concept 'God' stand in for any divinity or divine or sacred story or ultimate reference, because to reflect on the presence of God can mean various different things depending on the tradition from which one views the divine or God? It could, for example, be what Stephen Crites (1989:69) calls the sacred story. Or it could refer to how sociologists such as McBrien (1987) describe religion:

\footnotetext{
... the whole complexus of attitudes, convictions, emotions, gestures, rituals, symbols, beliefs, and institutions by which persons come to terms with, and express, their personal and/ or communal relationship with the ultimate reality (God and everything that pertains to God). (p. 11)
}

According to this thinking, God's presence can therefore be interpreted as the ultimate reality or ultimate reference or ultimate good (Neuhaus 1984:256). Geertz (1993) describes religion as:

a system of symbols which act to establish powerful, pervasive, and long-lasting moods and motivations in humanity by formulating conceptions of a general order of existence and clothing these conceptions with such an aura of factuality that the moods and motivations seem uniquely realistic. (p. 90)

Berger (1967:32) argues that religion forms 'highly theoretical constructions by which the nomos of a society is legitimated in toto in which all less-than-total legitimations are theoretically integrated in an all-embracing Weltanschauung'. Religion thus offers the ultimate founding myth or legitimisation of what is (ontology of a particular worldview), which brings it into close proximity to Benjamin's (1996) founding myths that legitimise and give authority to laws and norms of a particular society. Religion can thus be broadly understood as religare - that which binds a particular worldview together as a whole.

Thus, a reflection on God or God's presence is basically a reflection on the ultimate reference, ultimate myth, of a particular community. It is a reflection on the ultimate founding myth of the particular worldview, in other words a reflection on the divinities of that specific Geviert (see Heidegger's fourfold, 1971:179) of a particular Dasein. In a postfoundationalist approach this would be the only way to reflect on the presence of God. If it is a Christian community, then the reflection on God would be a reflection on how the Christian metaphors and narrative resources shape and form the interpretation of that community's ultimate reference or the founding myth of that particular Christian community and thus help to make sense of the specific experiences within that particular context.

What would differentiate such a reflection on the presence of God in Müller's approach from the focus on God or divine or religion from a sociological point of view? This question is also raised in Louw's (2011) article when he asks: 'what is meant by the theological dimension implied in the empirical dimension of the praxis of practical theology?' Or in his later question where he asks: 'what is theological in the praxis of practical theological reflection?' (Louw 2011:5). Van der Ven (2004:332) echoes this question with his argument that practical theology, to be theological, needs to focus on divine action otherwise it could just as well be in the faculty of social science. What would qualify as a focus on divine action? This question raises the question of intentionality - who is the intentional subject of 'theological or religious action'? Is it God or humanity? It is difficult to separate these two as Van der Ven argues, because believing that God acts alone is a human construction, or a human confession (see Van der Ven 2004:367) and confessing is a human action, thus God's action cannot be neatly separated from human action. Ganzevoort (2009) interprets practical theology as the hermeneutic of lived religion to come to an understanding of the heart of practical theology. It is theological because it includes in its focus the religious component, which Ganzevoort (2009:n.p.) describes as follows: 'I would define religion as the 
transcending patterns of action and meaning embedded in and contributing to the relation with the sacred.' Concerning the sacred he writes, '... the sacred at least implies that it is a center around which one's life gravitates and a presence that evokes awe and passion'. With the term 'lived' he focuses specifically on how communities live 'more adequately in relation to the sources of religious tradition and to the ideas about the divine' (Ganzevoort 2009:n.p.), thereby linking practice to both what can be understood as textual studies (or the studies of sacred texts in various religious traditions) and systematic theology or the reflection and formulation of ideas about the divine or sacred. Therefore his understanding of practical theology does not deviate from what was argued in the first few paragraphs - that practical theology is the relationship between Text and context. What has broadened is that various different texts of other religions are included as well. Hermeneutics is interpreted by Ganzevoort (2009:n.p.) as understanding lived religion 'from its own characteristics and in light of its own understandings and intrinsic normativity'.

Although the shift to lived religion and understanding practical theology as a hermeneutic of lived religion broadens the theory-practice, or Browning's theory-laden practices, to include the practices of other religions, this broadening of its scope does not adequately answer the question, what makes it theological rather than sociology of religion. The focus here will be on the question: what makes postfoundational practical theology theological, if there is not a single dominant tradition or foundation? It would be un-postfoundational to make the Christian tradition normative or foundational and thus it needs to remain open to other religious traditions. Yet in Ganzevoort's (2009) approach, the sacred texts and ideas about the divine still play a normative role in interpreting lived religion and therefore I would argue that that approach cannot be understood as postfoundational, as it is an interpretation within the context of that specific lived religion's foundations.

On the other hand, one could argue that if the reflection on God from a Christian perspective (historical theology and systematic theology) is not normative or guiding, what then distinguishes practical theology from sociology of religion?

Before I focus on these questions I will shortly mention the last two movements of Müller's (2004:300) seven movements of postfoundational practical theology. The sixth movement is a description of experience, thickened through interdisciplinary investigation. The last movement is the development of alternative interpretations that point beyond the local community. On what basis are alternative interpretations developed that point beyond the local community? The alternative interpretations emerge through the interdisciplinary (thickened) descriptions. The question concerns the role of power in these interdisciplinary conversations. The powerful discourses will determine the alternative interpretation, which will then be a normative interpretation according to the norms of the powerful discourses. These alternative (normative) interpretations will certainly point beyond the local as they will be in harmony with dominant global discourses. If power is not taken into consideration then therapy or research will become ways of conforming to dominant discourses, bringing the client (therapy) or theory (research) in line with the Big Other. To prevent this conforming depends on the role the Big Other plays in all seven movements and therefore is a question of theology.

\section{The theology of postfoundational practical theology}

What is theological about practical theology from a postfoundational perspective? Postfoundational practical theology can be interpreted as being theological where God's action, revealed in Christ, is the hermeneutical centre of the whole approach of all the movements rather than only one of the movements. In other words, God, as revealed in Christ, is not only a theme to be reflected on in one of the seven movements, but a certain postmetaphysical interpretation of God informs the spirituality of the whole approach. A postmetaphysical interpretation of God, where the shift is away from 'transcending patterns of action', has the possibility of being a non-religious method to interpret and engage lived religion critically.

To be able to say that and make such a strong claim, certain things need to be unpacked. Where would such a theology begin? Theology would begin where one always already is, namely within the context of Dasein, that is, not the context in general, but the particular context of a particular Dasein (beingthere-in-a-particular-world). The focus is on particular texts ${ }^{1}$ (persons, experiences, practices, actions, phenomena) within their particular infinite chains of texts which forms a web of texts, namely a context: archi-writing. Context, understood as that in which text(s) are embedded, and thus the context shapes and co-determines the meaning, value and identity of the texts that find their home (habitus) with a particular web of texts that form the context or the archi-writing of that text. A text, on the other hand, is everything that can be identified, named, has meaning and is interpreted and, as such, it is writing, namely the construction of meaning through signs. This understanding of text and context is developed from the linguistic turn in the thinking of Heidegger (1971) and Derrida (1997). Heidegger refers to language as the house of being. Yet, this house of being is taken for granted and, as such, it is not noticed, because it is the silent speaking of language that is forgotten or is not heard as one's world appears to one as natural or God-given. The world as it 'is' for me is not perceived as a social construction, but is perceived as the way it truly is in reality! It is that way because it is obvious, natural or God-given, one argues, finding it difficult to comprehend that what is, is only my or our social construction of what is. Yet, it is not obvious, natural or God-given, but socially constructed by the particular house of being, the particular language of my Dasein. This is the silent speaking of language that is concealed in the unconcealment of all experiences and

1.I follow Ricoeur (1973:91) when using the word 'text' to refer to the objects of sociological research. 
practices, that the practical theologian seeks to describe, understand and interpret.

One is not conscious that the various texts (actions, experiences, phenomena) are embedded within a particular context that gives these texts meaning, value and identity, as it is the silent speaking of language. The silent speaking of language is where things (texts) carry out a world (context) and world (context) grant place to things (texts) (see Heidegger 1971:200). In other words, things (texts) have meaning because they are embedded and thus find a home or a place within a context and it is this context that gives them place: meaning and identity. This mutual carrying out and granting place is the silent speaking of language in and out of dif-ference (Austrag) (Heidegger 1971:200ff.). The silent and forgotten speaking of language is all there is as there is nothing outside text or context (see Derrida 1997:58).

This is the place where theology already is - the place (context) of one's Dasein: Being-there-in-the-world-withothers, but language is the house of this being-in-the-worldwith-others. Therefore one can argue that one is in language, and the infinite chain of texts within contexts, informing and referring to each other, but never reaching that which is beyond text or outside of text, that is the habitus of Dasein and thus it is in language, the house of being, that practical theology already finds itself.

If there is no way beyond text, this fundamentally wounds all metaphysics, or said differently, it inscribes all metaphysics within text and there is no beyond inscription. Therefore one can speak of a postmetaphysical approach. Theo-logy is one such inscription if it is understood as an attempt to understand or think or talk (logos) about God (theos), unless God is interpreted (inscribed) differently.

The tradition known as negative theology realises that it is impossible to talk of God and therefore they realise the impossibility of theo-logy. It is this tradition that Derrida engages to understand the proximity and difference of différance to negative theology (see Derrida 1995, 2008; Meylahn 2013b:226ff.).

The impossibility of speaking of God in the negative theological tradition is similar to the impossibility of speaking conclusively about anything, because everything is in language and therefore characterised by différance. Therefore, the negative theological impossibility of saying anything definitive and conclusive about God is true for everything, as Derrida says 'every other is wholly other (tout autre est tout autre)' (Derrida 1995:74). One is always already in language and any attempt to get beyond language is impossible. All that such an attempt to get beyond language (outside the text) achieves is the discovery of an infinite referential chain of signifiers. This infinite referential chain can also be referred to as the infinite desertification of language, which Derrida, in reference to the God of negative theology, argues is a good name for saving God (Derrida 1995:56). It is not only a good name for God, thereby saving the name God, but it also keeps God's name safe from idolatry. As God is a name worth saving and by saving it, as the name for this infinite desertification, God is saved from the idolatry of the names and concepts of God (see Derrida 1995).

Negative theology reveals something of the essence of language, namely prayer. Just as the prayer of negative theology is a way to cross the desert, the abyss, as it is a response to the call of the Other in the address to the Other, so is language an attempt to cross the abyss (the endless desertification of language) in response to the call of an other as an address to an other. Prayer is language and thus one can follow Caputo (2006) in his idea of theology of the event as an inner textual event. Theology, as theology of the event, is something that happens in texts and between texts as a prayer for the coming of the other, which is another way of speaking of auto-deconstruction: that which breaks texts open for what is still to come - a certain messianism without messiah (Derrida 2002).

The danger in Caputo's interpretation of Derrida is that différance can then become one more philosophy (or in this case theology) of difference, as Laruelle accuses Derrida of (see Laruelle 2010). In other words, that this theology of the event develops a kind of philosophy of difference between text and 'reality', even if that correlation is a correlation of non-relation relation or a relation of difference (see Meylahn 2013a).

Even thinking God as event, (Caputo 2006) or as the God who may be (Kearney 2001), could lead to a philosophy of difference as it is still a construction of the Other. It is for this reason that I would like to move beyond seeking to know God or to know the other who is every other. One cannot know God! God is beyond knowing, but so is every other. All we have is text (Derrida 1997:58). Laruelle (1999, 2001, 2003) radicalises this statement of Derrida by arguing that all we have is a vision-in-One. It is this vision-in-One that is the focus of practical theology as practical theology focuses on what is at hand (what one has access to): the practices and daily experiences. That is all one has: all there is, is text and no outside text.

There are two good theological reasons to have this focus on the vision-in-One rather than seeking various theologies of the Other. The first is a biblical text that invites believers to have this focus rather than seeking to know the Other, namely John 14:7. The other is from the protestant tradition and Luther, following Paul with regards to not knowing anything but Christ crucified (1 Cor 2:2), who had very strong words for any theologian that sought to seek God outside of Christ crucified. ${ }^{2}$

If God is sought elsewhere than in the cross that theology becomes a theologia gloriae. Theologia gloriae, in the context of the above, can be described as religion or the sacred canopy of our world-creation: that is, an idol - a human social 2.See Theological Theses 18-25, and their corresponding Proofs, within 'The Heidelberg disputation' (Luther 1518). 
construction. Any other theology, but theologia Crucis, is idolatry and therefore the shift from theology to Christology, but where the logos is crossed out - not erased, but crucified, so as not to become an idolatry in itself. Crossed out (crucified) so as to not become a way of seeing or thinking or understanding, as that would lead to work-righteousness and vainglory. A logos would be a work-righteousness and therefore the logos needs to be crucified so as to remain utterly dependent on text (scripture), Christ, faith and grace alone.

Is there a God beyond these human constructions? This is something one cannot conclusively argue for or against, as whatever argument one would propose would again only be a text: construction or idol, that is to say, a particular and therefore a context dependent theologia gloriae. One cannot conclusively argue for either atheism or theism as both are social-constructions and in that sense theologia gloriae or a-theologia gloriae.

Therefore, the focus should rather be with the One or Visionin-One as revealed in the narratives of Jesus. Focus on the incarnation and immanence, rather than on the impossibility of access or knowledge of transcendence or the Transcendent. Therefore the focus will not be on the Other that breaks into texts, as there is not much point in speculation about the other, but the focus will be on the Other made in human likeness (Phlp 2:5), the Other made text, or the Christ-Ereignis as an inner-textual event. I will argue for a Christolegy or the Christ-Ereignis. ${ }^{3}$

\section{Postfoundational practical theology as Christology}

If one is always already in the text, and therefore theology will always already have started, then the theologian today comes to that which has already begun only to witness the Christ-Ereignis within and between texts in their contexts. The place to 'start' is where one already is, in a particular Dasein of a particular silent speaking of language where one seeks to understand an experience or practice or action (text) within its infinite referential chain of texts forming the contexts.

This focus on Christ is certainly easier said than done as there are so many different interpretations of Jesus. The New Testament alone contains at least four versions of Jesus. One would have missed the whole point if one sought to identify a particular image (construction) of Jesus as the symbol or sign of God. The Carmen Christi (Phlp 2:5-11) points one in a different direction of understanding Jesus as the One. He is the One, as he is the one who did not seek equality with God, but emptied himself of all divine content (Transcendent content). He did not seek to be a true and correct presentation of the Other, but emptied himself of all ambition to be just that, as there was no content of the Other in him. He was an empty symbol of the Other. Ray Brassier's (2001:273) concept of a radical-hyle in response to
Laruelle's non-philosophy might help in understanding this kenosis of all Other (divine) or Transcendent content. The radical-hyle 'enacts matter's transcendental foreclosure to thought within thought' (Brassier 2001:10). The radical-hyle enacts the other's foreclosure to thought within thought. A radical-hyle is a non-conceptual symbol, in other words it is not an empirical conceptualisation of matter (the other) nor a transcendental materialisation of the concept (see Brassier 2001:273). If anything it is an axiomatic heresy (see Brassier 2003). An axiomatic heresy that can be embraced in faith alone as a gift (grace alone), without any philosophy of correlation or philosophy of difference (see Laruelle 2010) to substantiate it and thus text (inScription) alone and nothing outside of text. Jesus, interpreted as radical-hyle, as a nonconceptual symbol, as an axiomatic heresy that can only be embraced in faith and as a gift. If Christ is interpreted in such postmetaphysical metaphors as a radical-hyle and/ or axiomatic heresy, then one can speak of a Christology or science of Christ (see Laruelle 2008) as a non-philosophy philosophy or non-religion religion: a Christology, where the logos has been crossed out, crucified (see Meylahn 2013b:318f.).

The Christ-Ereignis is made up of three movements (incarnation - crucifixion - resurrection and ascension). These three movements will be read together with the five dance movements developed in Church emerging from the cracks (Meylahn 2012:53ff.) in an attempt to develop a postfoundational practical theology as public Christology.

Practical theologians, as Müller argues, begin their task by describing their context or the context in which they are working. Practical theologians seek to understand the various texts within their contexts (archi-writing) as the silent speaking of language of this particular Dasein. Yet, following the challenge of Philippians 2:5, they find themselves in this context with the same mind as Christ. The practical theologian, having the same mind as Christ, is emptied of divine content (content of the Other). They do not seek the truth of the context, because all they will find is their own truth reflected back to them, but they will seek to understand how these texts in context are unconcealed to them (received in their context) in a realm of the concealment (the silent speaking of the language of the context) and of their concealment (the silent speaking of their language). Thus, in following Christ one finds oneself incarnated, embodied in a particular Dasein, as one seeks to understand and interpret the embodied experiences of others in the silent speaking of their language through one's own embodiment in the silent speaking of one's language. The task of doing theology in this first moment of the Christ-Ereignis is the first two steps of the five dance movements, which is to listen ${ }^{4}$ and to interpret $^{5}$ (see Meylahn 2013b:53). In other words, two world-

4.Listening (double listening): listen to the dominant common language of the particular context; listen to the shadow stories that are suppressed, excluded, ignored and marginalised, but question the dominant common language of the particular context.

5.Interpreting: the particular stories (texts) need to be read within their contexts. To read the various particular texts within their contexts can only be done with the help of other disciplines and thus this is an interdisciplinary approach. Part of the narrative setting (contexts) of the particular stories (texts) is the sacred story or the narrative setting (contexts) of the particular stories (texts) is the sacred story or the
story of ultimate reference which binds (regilare) into a particular community. This sacred story (religion) needs to be read and interpreted. 
creations meet each other and, in that meeting, there is a new world-creation (poiesis): the world-creation of the practical theologian and the world-creation of the community and the new world-creation of the fusion of horizons of these two. All these world-creations have dominant myths, sacred canopies or Heidegger's divinities of the Geviert. The theologian's task, as theologian, is to identify these gods (divinities), dominant myths (ultimate references), that present these world-creations as God-given or natural, that is, as absolute: as the way things are or should be - the dominant myths that provide the ultimate legitimisation and norms to present the world as is, with its particular ontology. This critical engagement with the dominant myths, discovering the gods of the contexts, is the third movement: discernment, ${ }^{6}$ discerning the powers that be, recognising the religion as the founding and legitimising myth of each of these worldcreations, and that binds (religare) this world together into a whole. The focus of this approach is on the religious of various life-worlds or on the religion of lived-religion.

The critical discernment is not on the basis of having eaten of the tree of knowledge of good and evil and thus being in a superior position to judge the various gods on the basis of some or other sacred text (historical theology) or sacred idea (systematic theology) or foundation, but is rather a humble recognition that each context, even one's own context of critical discernment, has its gods. The result could be interpreted as frustrating as one would be left with numerous world-creations, each with their gods and without a hyper-perspective or transcendent position from which to judge, as each of these contexts with their divinities is equally valid. Now, one could follow Browning (1991:71) who developed, in conversation with Habermas (1984, 1996), five universally acceptable validity claims whereby to judge certain world-creations. Church emerging from the cracks (Meylahn 2012) presents an alternative route to Browning and follows Christ's bias for the least of the brothers and sisters, to recognise the marginalised and ostracised and become neighbour (see Meylahn 2009) to them within a particular Dasein of a particular world-creation. That is, to seek the shadow stories of that world-creation, conscious that the choice of shadow stories is one's choice determined by one's own world-creation with its particular divinity: legitimising myth. For example, a feminist would choose the marginal voices of women and a Marxist would choose the marginal voices of the exploited workers and this choice would be determined by their Marxist or feminist worldview with their respective divinities (founding myths). There is no 'correct' choice of marginal voices as each choice creates its own marginal voices and therefore keeps the practical theologian following Christ humble.

The chosen marginal voices or shadow stories haunt the dominant myths, as these shadows stories question the validity of the dominant myths. The very existence of the

6.Discerning: the sacred story needs to be discerned as ultimate myths or ideology, not judged from an outside (God's view), nor by comparing them to a higher authority or higher myth, but from within the intertextual context. These ultimate authority or higher myth, but from within the intertextual context. These ultimate
myths as totalising myths have many victims - marginalised and ostracised shadow myths as totalising myths have many victims - marginalised and ostracise
stories (texts) that question the ultimate authority of these sacred texts. shadow stories questions the ontology of the world-creation, as according to the norm these shadow stories should not exist, yet they do and thus their very existence question the ontology and, by questioning the ontology, they question the legitimising and authoritative myth of that specific ontology. The shadow stories (marginal or ostracised voices) by their very non-existence existence unbind the binding force of religion. Jesus' becoming neighbour (see Meylahn 2009) to these shadow stories blasphemes (questions the authority) the dominant myths and thus the powers that be had to destroy this ultimate criminal who challenged both their ontology as well as their founding myth (god). He is the ultimate criminal because he threatens, by loving the unloveable and accepting the unacceptable, to unbind their whole world as this love and acceptance threatens to untie their world from the sun or murder their gods (see Nietzsche 1974:181-182). The powers that be reacted to this challenge by crucifying Christ (1 Cor 2:8) as a blasphemer, as one who challenged the founding and legitimising myths. The blasphemy is not the cross, but the incarnation and ministry. The cross is the blasphemy of blasphemy and thus the utter forsakenness by God. One could argue that God (the divine) died in the incarnation and that the crucifixion is the death of the death of God (see Meylahn 2013b:316f.). In other words, the crucifixion is the death of the certainty of atheism which does not translate into theism, but the utter uncertainty, of being utterly forsaken of any foundation, even the foundation of the way of Christ, and therefore the logos of Christ is crucified: Christology (see Meylahn 2013b:316ff.). But in that crucifixion is the birth of the impossible possible: resurrected life.

Practical theologians, by seeking to have the same mind as Christ, open themselves to the marginal and thereby open themselves to being labelled blasphemers as they challenge, by their association with the least of the brothers and sisters, the dominant legitimising myth. They challenge and thus blaspheme the gods of the various world-creations by becoming neighbours to the shadow stories. This fourth movement is described as re-interpreting or re-authoring 7 (poeisis or poetics of the kingdom) the particular stories of the context by an intertextual reading between the stories of the context with the stories of Christ and witnessing how the shadow stories challenge the dominant myths and reading that in light of Christ's incarnation and ministry. The Gospel of Jesus is interpreted as an exemplary narrative of that which happens in texts (deconstruction because of différance) ${ }^{8}$ (see Meylahn 2013b:310f.). Following Christ into the incarnation

7.Re-authoring (poiesis): the movement of re-authoring already begins with the previous movement of discernment. This movement is the re-reading of the texts within their contexts in the light or intertextual reading with the story of Christ, as the story of the world.

8.Why can one translate the Christ-Ereignis into the post-metaphysical metaphor and imagination of différance? Has a new truth been found? Has the 'correct' interpretation of Christ been found? No, I could not have done otherwise as the letter arrives at its destination. Can the West think beyond Athens and Jerusalem, or will Athens and Jerusalem always be part of thinking from a Western perspective? The Bible and the writings of the Greeks are part of the West's mythology. They The Bible and the writings of the Greeks are part of the West's mythology. They form part of the West's narrative resources and thus imaginings. Postmetaphysic developed out of this fertile ground and thus the imaginings of postmetaphysics are within the metaphors of both Athens and Jerusalem, amongst others. There is no outside text and therefore there are no imaginations outside the texts of the West for somebody whose context is influenced by the West. Could it have bee otherwise - that these two inter-texts translate into each other? Perhaps, as the letter does and possibly does not arrive at its destination, as it is haunted by a Christology or différance. 
and crucifixion by becoming neighbour to the shadow stories, the practical theologian witnesses the auto-deconstruction of the gods. The theologian does not deconstruct (on whose or which authority would he or she do that?), but the theologian is a witness to the auto-deconstruction that happens once he or she becomes neighbour to the shadow stories. In that autodeconstructed space something new can arise: resurrection. A new community, liberated from the dominant norms, legitimised by the dominant myths, and therefore a community where there is neither Jew nor Greek, man or woman, free or slave (G1 3:28) or any other categorisation by which ontological place is given to things within a particular world, legitimised and authorised by a particular myth.

This new community is not the answer, because in its resurrection and its understanding of itself as a new community it creates a new sacred canopy. The moment the new community is conscious of itself as new community and bound together (religare) as a community it will have formed its own authorising and legitimising myth, which excludes and creates shadow stories.

One of the last thoughts Nietzsche penned down to his friend Georg during the final stages of his illness, as quoted by Heidegger: 'After you had discovered me, it was no trick to find me: the difficulty now is to lose me ... (signed) The Crucified' (Heidegger 1968:53). Once the community has found Christ as its liberating source, it needs to lose Christ before Christ becomes an ideology. Thus, the Christological community is a community that can never be, but is always still to come. It is a community that is dependent on the gift (sola gratia) of the Christ-Ereignis (sola Christus) that is witnessed and received in faith (sola fide), through becoming neighbour to the shadow stories whereby the dominant myths are auto-deconstructed as an inner textual event (sola scriptura). Carl Schmitt (1976) argues that the loss of enemies is the death of the political. The Christ-Ereignis is the death of the political as such, because no community can be formed in this continuous challenge to love enemies. It is the death of theory (logos) as well, because any theory is continuously deconstructed by that which the theory excludes or does not say and therefore it is the death of logos. But logos cannot die just as little as metaphysics can die, but it can be thought through and thus be wounded - always open to the future (see Laruelle 2003:181) and therefore a crucified loges.

The last dance movement develops this idea of the community always to come in its embracing listening. ${ }^{9}$ The new needs to be embraced, but very conscious that in that embrace new margins are created and in those margins and cracks of the resurrected community are shadow stories that need to be listened to. The new community is embraced, but conscious that it needs to already begin to listen to the shadow stories of its own creation and therefore it remains a community to come. The new community can never be, but is always to come and thus it is a community that is continuously

9.Embracing - listening: a dance without end in the time that remains. New lifegiving words are poetically formed and unique outcomes are discovered that can be embraced. These unique outcomes are not the final story, but they need to be listened to, discerned and re-authored in the time that remains. reforming (ecclesia reformata), not by human will or power, but by what is happening in the texts of the community where the church or the theologian finds herself (verbum Dei).

\section{A working description for postfoundational practical theology}

I would like to propose a working description for practical theology as public Christology. Practical theology is to witness in love, to bear testimony in faith and to receive the Christ-Ereignis in grace as an inner-textual and intertextual event in reading texts within their contexts and embracing the space of hope that such double reading creates to continue reading in the time that remains.

This proposed description of practical theology is a way of reading, but a way is still too strong a concept as it reminds one of a praxis (theory-laden practice) which functions on the basis of certain foundational knowledge which guides and determines the way (practice) as its theory. Thus, I would not opt for Edmund Arens' (1992) concept of Christo-praxis, which he develops in conversation with Habermas' (1984) communicative action, as that would be too strong a term to use. Christo-praxis would be guided by the theory of communicative action.

Instead of a way it is more a Gelassenheit or spirituality of love reaching out and an expectant hope to witness the ChristEreignis which disclosingly appropriates a new community without disclosing anything and without being able to appropriate anything but hope, faith, grace and Christ, in text, through love alone. It is a spirituality of reading with a particular hermeneutic of love for marginal stories. The hermeneutic of love for marginal stories is inspired by hope expecting to witness the Christ-Ereignis and through faith to give testimony to that Ereignis in an inner-textual and intertextual reading. An intertextual reading where the Christ-narratives are read together with the autodeconstruction that happens in texts when one finds oneself neighbour to the marginal and shadow stories in the texts. This reading together is a theo-poetics, ${ }^{10}$ or rather a Christopoetics, where what happens in texts is interpreted with the help of the Christ-narratives so that one can witness and give testimony to the Christ-Ereignis as Christo-poetics. Christo-poetics is a poiesis and in that sense a construction, but also not a construction as it lacks the foundations of a construction, lacks order and completion of constructions and thus it is, if anything, a vulnerable temporary creation (poiesis): Christo-poetics that is vulnerable and wounded, like the lamb that was slain that enters the throne room to unlock the seven seals of history ( $\operatorname{Rv} 5: 6)$.

This spirituality, or Gelassenheit, is reading texts where one finds oneself neighbour to the shadow stories and witnesses

10. What is important for theo-poetics and which prevents it from becoming theopoetry and eventually theo-politcs is that theo-poetics does not have an author, there is no conclusive meaning, there is no order, but always complexity, and there is no end, but openness to what is still to come (see Meylahn 2013b:301ff.). Thus, although theo-poetics is a kind of social-construction (a poiesis), there is an important difference in the four characteristics of theo-poetics: no author, no conclusive meaning, no order but complexity, and no end but openness to what is still to come. 
the blasphemy of the dominant myths, and therefore the crucifixion, and interprets this happening through a Christopoetics by an intertextual reading of the Christ-Ereignis with the auto-deconstruction that happens in all texts because of différance. Although such a reading is a temporary vulnerable poiesis, it is also a fragile universalism, as it is a witnessing of auto-deconstruction as something that happens in all texts because of différance. Thus, this spirituality of reading is a reading of all texts and therefore it is a public spirituality as it is a spiritual reading of public texts, it is an academic spirituality as it is a spirituality of reading academic texts and a church spirituality as it is a spirituality of reading the texts of the denominational traditions. A Christolegy is a spiritual sense of not-being ${ }^{11}$ because of love's call to become neighbour to the marginal voices in reading the texts in all three of Tracy's (1981:3-31) publics: academia, public and church. The theologian becomes neighbour to the marginal voices and therefore shares the non-being status of the marginal voices to reduce to nothing the dominant discourses of these three publics and, engaging the texts of these publics with a love for what is not said, becomes neighbour to those marginal voices in the dominant discourses with a sense of expectancy for the Christ-Ereignis. Christology is not at home in any of these publics. As it is spirituality of non-being it does not have a home, like the son of man who does not have a place to lay his head (Mt 8:20). Thus Christology is, if anything, disruptive in the three publics. It is not a logos and thus, if anything, it is a folly (1 Cor 1:27) to put to shame the wisdom of the world - the wisdom that binds (religare) these publics into an identifiable entity. But it is not a folly in the sense of a morosophia (see Meylahn 2013b:325ff.; Phan 2001) but, if anything, rather in the sense of the salos (Byzantine Holy Fools of late antiquity and early Middle Ages) whose openness to the Other allowed their continuous self-deconstruction (see Meylahn 2013b:331). Yet, its fragile universal practicality cannot be denied in all three publics, because by becoming neighbour to the marginal and shadow stories, and by becoming neighbour witnessing the autodeconstruction of dominant societal, academic and church discourses, they are opened up for democracy and justice always still to come, Derrida (2005:78-94) would argue. Thus, by being a spirituality of non-being it has no home and yet its homelessness and folly plays an important role in the various discourses as it opens these discourses for the future still to come and thus it is a discourse of the future - future being its only home: the kingdom to come.

\section{The church or the community of a postfoundational practical theology}

Where does such a practical theology leave the church or the community of believers or the resurrected community that is always still to come? What kind of community is the 'church'

11.There are enough references throughout the New Testament for the call to nonbeing of the Christian. There is the call to be in the world, but not of the world (Jn
17:14-15), as well as the call not to conform to the patterns of the world ( $\operatorname{Rm} 12: 2$ ). 17:14-15), as well as the call not to conform to the patterns of the world (Rm 12:2). In 1 Corinthians 1:28, God's choice of those that are not to reduce to nothing thing that are echoes - something of the call to auto-deconstruction through becoming neighbour to those who are not so as to reduce to nothing those that are (th dominant discourses). Even more radical are Jesus' calls to become nothing (death) for the other as a call to discipleship in John 15:13. In Matthew 16:24, there is the call to deny yourself and pick up the cross to become a disciple. that is always still to come and yet, because of its spirituality of love, it witnesses and gives testimony to the disruption (putting to shame and bringing to nothing) of the dominant discourses in the various publics? Does this witnessing and testimony fulfil the criteria for communicative action? Does action not require there to be a purposeful intentional subject who can be held responsible for the action? From the above description, the theologian would have as his or her main 'action' to read with a spirituality of love and through love witness and give testimony to the Christ-Ereignis. Could the theology then be described, in reference to Habermas $(1984,1996)$, as communicative action and the church as a community of communicative action?

Habermas's theory takes the linguistic turn seriously and yet seeks to develop a grand theory of normativity and validity and thus finds himself a defender of modernity rather than an advocate of postmodernity. It is probably this defence of normativity and validity that makes him an interesting conversational partner for practical theology (see Arens 1992; Browning 1991; Heitink 1999; Peukert 1984; Van der Ven 2004). Robert Mager (2012:258) argues that it is the theory of action which is both descriptive (analytical) and prescriptive (normative) which attracted practical theologians. The analytical (descriptive) side of action theory helped theology to gain acceptability within the academic public as a serious analytical modern science and the prescriptive helped practical theology to remain true to God (God's gift or plan or law) (see Mager 2012:258).

Does practical theology have to gain acceptability in the university (as the place for academic discourse) or should it be disruptive of these discourses, in other words, play the jester in the academic discourses rather than theology's previous role as queen of the sciences? Should practical theology be prescriptive? The above working description interprets a practical theology as Christology that does not seek acceptance in academic discourse, but is disruptive; nor does it seek to be prescriptive and yet it witnesses continuous transformation.

In action theory, specifically communicative action theory, to be the subject of action one has to be and have intentions that can be justified via universally valid claims. ${ }^{12}$ Yet God has chosen what is not (non-subjects), to shame what is (1 Cor 1:28). Thus the chosen, the elect, are not (nonsubjects) for a specific purpose: to shame what is. In the testimony of the Christ-Ereignis, the theologian (church) does not utter something understandable, but something disruptive, challenging the ontology and the metaphysics of that particular world (public). As Heidegger argues, truth, rightness and truthfulness - if it is understood as correlation or adequate representation of something (facts; norms for interpersonal relationship or a speaker's subjectivity)

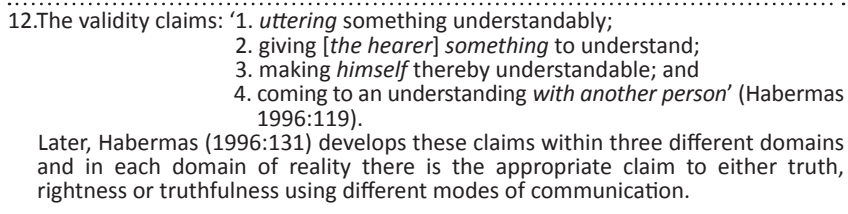

Later, Habermas (1996:131) develops these claims within three different domains and in each domain of reality there is the appropriate claim to either truth, rightness or truthfulness using different modes of communication. 
- forgets that aletheia is always an unconcealing in concealment (see Heidegger 1984:§§24-24). Thus, questions of truth, rightness and truthfulness are dependent on the Gesichtskreis of unconcealment and the dominant discourses within that Gesichtskreis. These dominant discourses will determine the legitimising myth, the norms and thus the ontology according to which the truth is measured and so the dominant discourse will always find its truth, rightness and truthfulness reflected back at it in the various publics (domains). As Lacan (1972) argues, in references to Poe's Purloined Letter, the letter always arrives at its destination, or as mentioned in the beginning, the theologian will find his or her truth, rightness, truthfulness reflected back at himself or herself. Derrida (1975:107) challenged Lacan's interpretation, arguing that the letter might and might not arrive at its destination. It is this 'might not arrive at its destination' that inspires the Christological approach to seek not to be a valid discourse in Tracy's three publics or the three domains of Habermas, but rather to be a disruptive discourse in these publics and domains. A public Christolegy does not give that particular public something to understand, but questions that public by opening it for what it excludes. It does not make itself understandable, but becomes nothing, even to the point of death, to challenge what is. It does not come to an understanding, but creates space for new understanding. And yet, in the Christo-poetics of testimony, there is something sensible (understandable) which is communicated that is liberating: the hearers do receive the good news, the ChristEreignis is made understandable and a new community of temporary fragile understanding is created. It is a message that is communicated and understood in the witnessing of the subversion of the dominant, acceptable and normative discourses, not with a better foundational discourse, but with what is to come: the future.

Edmund Arens (1994:34), in conversation with Habermas, seeks to understand the communicative action of the church, her Christo-praxis, according to five characteristics: intersubjective, propositional-performative, textual, contextual and it has an intentional character. How would Christopoetics differ from such a Christo-praxis? The Christological spirituality of non-being would agree with it being intersubjective, textual and contextual. The problem is with propositional-performative and intentionality.

Does the Gelassene reading, which is a spirituality of love, have a propositional-performative character? Propositional from the Latin, prōpositiō, means to set out in words. Christopoetics sets out in words, but the difference is that it is not the subject (author) that sets out in words something that the words refer to (that can be validated as objectively truthful, right according to the dominant norms, or truthful of a specific subject), but the subject finds himself or herself set out in words, in text (language) and, in that text, he or she witnesses the Christ-Ereginis, as a disruption of norms of rightness and a disruption of identity and character. The action has to have a propositional-performative character, in other words it does not only seek to set out in words, but it seeks to change the reality it sets out in words. In the above paragraphs, it was made clear that Christo-poetics changes the reality as it opens reality for what is still to come. The question is: who is the author of this change? Or stated differently, who is the subject of this performance? The theologian of the Christology is witness of the Christ-Ereignis and not the author thereof. Thus the subject of the 'action' in this communicative action theory of Habermas is not the practical theologian or the church, but he or she is only the witness thereof and testifies to what has been witnessed via Christo-poetics. The subject of that action is the grammatical structure and incompleteness of language itself (God as the infinite desertification of language), which is interpreted with the help of the Christ-Ereignis.

The intentional character of this spirituality would be love for the marginal, but again it is not an active choice of deciding who my neighbour is, but rather a passive finding oneself in the position of being a neighbour to the marginal and shadow stories of the dominant discourses one happens to be part of. In the parable of the Good Samaritan, Jesus turns the question around from who is my neighbour, where the $\mathrm{I}$ is the subject of choice, to who was neighbour to this person (see Lk 10:25-37), where the I (subject) passively finds himself or herself being neighbour to the one in need. The intentionality is love and through love finding oneself neighbour to the marginal and there, in that non-place amongst the non-beings hoping to receive the gift (grace) of the Christ-Ereignis in the text alone and to give testimony to what one has witnessed. This Gelassene reading through a spirituality of love, although it is not completely passive, certainly cannot be described as a performative action of an intentional subject who is in control and motivated with clear deontological or teleological foundational reasons for his or her actions, but can rather be described as a receptive or Gelassene openness to the Christ-Ereignis in the desire to have the same mind as Christ. The local church can therefore not have an intentional performative action plan, but in seeking to have the same mind as Christ it is open to witness the Christ-Ereignis and give testimony thereof.

Arens (1994:42ff.) argues that it is not only a matter of witnessing and giving testimony (Bezeugen), but also to confess (Bekennen), and it is in the confession that the church's action is communicated as an understandable utterance where something is understood, thereby making the church understandable and coming to a common understanding with others. The interesting thing about the word Bekennen is that it contains the word kennen (to know). What does Christological spirituality know? It knows nothing, but Christ crucified, therefore it knows nothing that is certain, fixed, foundational or conclusive, not even the certainty of uncertainty, and yet it can confess this lack of knowledge and its utter dependence on faith, grace, Christ and text alone. Is this confession of the four soli enough to create and sustain a community of praxis? No, it is not, but nor should it be, as the resurrected community can never be created nor sustained, as it is a community that is always still to come. Therefore the 
confession (Bekennen) of such a Christology is, if anything, a confession of non-being and the utter dependence on the four soli and a confession of being called to become an always reforming church that never makes complete sense in this world as it is a church in, but not of the world. It is ecclesia reformata, semper reformanda secundum verbum Dei. The church as such cannot exist because to love enemies, as Carl Schmitt (1976) tells us, is the end of the political, thus the church, called to love enemies, called to become neighbour to the least of the brothers and sisters, can never be church, but if anything only be a becoming church in the time that remains. It is a church of the future as the future is her home.

\section{Conclusion}

Postfoundational, not in the sense of non-foundations, but in the sense of thinking through foundations, like Heidegger's postmetaphysics, was a wounding of metaphysics (see Heidegger 2003; Meylahn 2013b:18f.), or Derrida's postmetaphysics was the closure, not end, of metaphysics (see Derrida 1997:4; Meylahn 2013b:194ff.). Postfoundational practical theology is thinking through the foundations, religion, or metaphysics of the various life-worlds and witnessing their wounds or crucifixion because of what they invariable exclude and therefore their opening for the future. It is a witnessing not on a basis of a foundation, but on what 'God does in language or history' (God as the infinite desertification of language) as revealed in Christ, thus opening the life-world for what is to come: the kingdom to come.

The postfoundational practical theologian is called to a public Christological spirituality of not-being, through becoming neighbour to the marginal voices in the texts of the various publics (academia, society and church) and there bear witness and in faith offer testimony to the Christ-Ereignis, as he or she in hope continues reading texts in contexts in the time that remains.

\section{Acknowledgements Competing interests}

The author declares that he has no financial or personal relationships that may have inappropriately influenced him in writing this article.

\section{References}

Arens, E., 1992, Christopraxis: Grundzuge theologischer Handlungstheorie, Herder Freiburg. PMCid:PMC50315

Arens, E., 1994, 'Leitlinien einer handlungstheoretischen Christologie', in E. Arens (ed.), Gottesrede Glaubenspraxis: Perspecktiven Theologischer Handlungstheorie, pp. 29-48, Wissenschaftliche Buchgesellschaft, Darmstadt.

Benjamin, W., 1996, 'Critique of violence', in M. Bullock \& M.W. Jennings (eds.), Walter Benjamin: Selected Writings, Vol 1: 1913-1926, pp. 236-252, Harvard University Press, Cambridge.

Berger, P., 1967, The sacred canopy: Elements of a sociological theory of religion Anchor Books, New York.

Brassier, R., 2001, 'Alien theory: The decline of materialism in the name of matter' PhD thesis, Department of Philosophy, University of Warwick.

Brassier, R., 2003, 'Axiomatic heresy: The non-philosophy of François Laruelle', Radical Philosophy 121, 24-35.
Browning, D.S., 1991, A fundamental practical theology: Descriptive and strategic proposals, Fortress Press, Minneapolis.

Caputo, J.D., 2006, The weakness of God: A theology of the event, Indiana University Press, Indianapolis.

Crites, S., 1989, 'The narrative quality of experience', in S. Haerwas \& L.G. Jones (eds.), Why narrative? Readings in narrative theology, W.M.B. Eerdmans, Grand Rapids.

Derrida, J., 1975, 'The purveyor of truth', transl. W. Domingo, J. Hulbert \& M. Ron, Yale French Studies - Graphesis: Perspectives in literature and philosophy 52, 31-113.

Derrida, J., 1995, 'Sauf le nom', in J. Derrida \& T. Dutoit (eds.), On the name, pp. 35-88, transl. D. Wood, J.J. Leavey \& I. McLeod, Stanford University Press, Stanford.

Derrida, J., 1997, Of grammatology, transl. G.C. Spivak, John Hopkins Press, Baltimore.

Derrida, J., 2002, "Faith and knowledge: The two sources of "religion" at the limits of reason alone', in G. Anidjar (ed.), Acts of religion, pp. 40-101, transl. J.F. Graham, Routledge, London.

Derrida, J., 2005, 'The last of the rogue states: The "democracy to come", opening in two turns', transl. R.-A. Brault \& M. Naas (eds.), Rogues: Two essays on reason, pp. 78-94, Stanford University Press, Stanford.

Derrida, J., 2008, 'How to avoid speaking: Denials', in P. Kamuf \& E. Rottenberg (eds.), Psyche: Inventions of the Other, vol. II, pp. 143-195, transl. K. Frieden \& E. Rottenberg, Stanford University Press, Stanford.

Failing, W.-E. \& Heimbrock, H.-G., 1998, Gelebte Religion Wahrnehmen. Lebenswelt Altagskultur- Religionspraxis, Kohlhammer, Stuttgart.

Ganzevoort, R., 2009, 'Forks in the Road when tracing the sacred: Practical theology as hermeneutics of lived religion', Presidential address to the 9th conference of the IAPT in Chicago, 30 July - 03 August, viewed 20 May 2013, from http://www. ruardganzevoort.nl/pdf/2009_Presidential.pdf

Geertz, C., 1993, 'Religion as a cultural system', in C. Geertz (ed.), The interpretation of cultures: Selected essays, pp. 87-125, Fontana Press, Waukegan.

Gräb, W., 2002, Sinn furs Unendliche: Religion in der Mediengesellschaft, Kaiser, Gütersloh.

Habermas, J., 1984, The theory of communicative action 1. Reason and the rationalization of society, Polity Press, Cambridge.

Habermas, J., 1996, 'What is universal pragmatics?', in W. Outhwaite (ed.), The Habermas reader, pp. 118-131, Polity Press, Cambridge.

Heidegger, M., 1968, What is called thinking?, transI. F.D. Wieck \& J.G. Gray, Harper \& Row Publishers, London.

Heidegger, M., 1971, Poetry, language, thought, transl. A. Hofstadter, Harper \& Row, New York.

Heidegger, M., 1984, “Grundfragen der Philosophie: Ausgewählte "Probleme” der Logik', in F.-W. von Herrmann (ed.), Gesamtausgabe, B. 45, Klostermann, Frankfurt.

Heidegger, M., 2003, 'Overcoming metaphysics', transl. J. Stambaugh (ed.), Martin Heidegger: The end of philosophy, pp. 84-110, University of Chicago, Chicago.

Heitink, G., 1999, Practical theology: History, theory, action domains: Manual for practical theology, transl. R. Bruinsma, W.M.B. Eerdmans, Grand Rapids.

Hofstadter, A., 1971, 'Introduction', in M. Heidegger (ed.), Poetry, language, thought, pp. ix-xxii, Harper \& Row, New York.

Kearney, R., 2001, The God who may be: A hermeneutics of religion, Indiana University Press, Bloomington.

Lacan, J., 1972, 'Seminar on "The Purloined Letter"', transl. J. Mehlman, Yale French Studies - French Freud: Structural Studies in Psychoanalysis 48, 39-72.

Laruelle, F., 1999, 'A summary of non-philosophy', Pli: The Warwick Journal of Philosophy 8, 138-148.

Laruelle, F., 2000, 'Identity and event', Pli: The Warwick Journal of Philosophy Parallel Processes 9, 174-189.

Laruelle, F., 2003, 'What can non-philosophy do?', transl. R. Brassier, Angelaki: Journal of the Theoretical Humanities 8(2), 169-189. http://dx.doi. org/10.1080/0969725032000162648

Laruelle, F., 2008, 'A Science of Christ', paper presented at the Grandeur of Reason: Religion, tradition and universalism conference in Rome, 01-04 September.

Laruelle, F., 2010, Philosophies of difference: A critical introduction to non-philosophy, transl. R. Gangle, Continuum, New York, Kindle edition.

Louw, D.J., 2011, 'Ta splanchna: A theopaschitic approach to a hermeneutics of God's praxis. From zombie categories to passion categories in the theory formation for praxis. From zombie categories to passion categories in the theory formation for a practical theology of the intestines', HTS Teologies
$67(3)$. http://dx.doi.org/10.4102/hts.v67i3.1087

Luther, M., 1518, 'The Heidelberg disputation', in The book of concord: Confessions of the Lutheran Church, viewed 31 August 2011, from http://bookofconcord.org/ heidelberg.php

Mager, R., 2012, 'Action theories', in B.J. Miller-McLemore (ed.), The Wiley-Blackwell companion to practical theology, pp. 255-265, Blackwell Publishing, Oxford.

McBrien, R.P., 1987, Caesar's coin, MacMillan Publishing Company, New York.

Meylahn, J.A., 2009, 'Responsibility, God and society: The cry of the Other in the sacred texts as a challenge towards responsible global citizenship', HTS Teologiese Studies/Theological Studies 65(1). http://dx.doi.org/10.4102/hts.v65i1.131

Meylahn, J.A., 2012, Church emerging from the cracks: A church in, but not of the world, Sun Media, Bloemfontein. 
Meylahn, J.A., 2013a, 'The hidden potential of pre-theoretical transversal events or advents of a Rainbow Nation', HTS Teologiese studies/Theological Studies 69(1). http://dx.doi.org/10.4102/hts.v69i1.1305

Meylahn, J.A., 2013b, 'The limits and possibilities of postmetaphysical God-talk: A conversation between Heidegger, Levinas and Derrida', Studies in Philosophical Theology 52, Peeters, Leuven.

Müller , J., 2004, 'HIV/AIDS, narrative practical theology, and postfoundationalism: The emergence of a new story', HTS Theological Studies/Teologiese Studies 60(1\&2), 293-306

Müller, J., 2011, 'Postfoundational practical theology for a time of transition', HTS Teologiese Studies/Theological Studies 67(1), Art. \#837, 5 pages.

Neuhaus, R.J., 1984, The naked plublic square, W.M.B. Eerdmans, Grand Rapids.

Nietzsche, F., 1974, The gay science, transl. W. Kaufmann (ed.), Vintage, New York.

Peukert, H., 1984, Science, action, and fundamental theology, transl. J. Bohman, MIT Press, Cambridge.

Phan, P.C., 2001, 'The wisdom of Holy Fools in Postmodernity', Theological Studies $62,730-752$.
Ricoeur, P., 1973, 'The model of the text: Meaningful action considered as a text', New Literary History - 'What is literature?' 5(1), 91-117.

Schmitt, C., 1976, The concept of the political, transl. G. Schwab, Rutgers University Press, New Brunswick.

Tillich, P., 1951, Systematic theology, vol. 1., University of Chicago Press, Chicago.

Tracy, D., 1975, Blessed rage for order, Seabury Press, Minneapolis. PMCid:PMC432634 Tracy, D., 1981, The analogical imagination, Crossroad, New York. PMCid:PMC1249447

Van der Ven, J.A., 2004, 'Towards a comparative empirical theology of mindful action', in C.A.M. Hermans \& M.E. Moore (eds.), Hermeneutics and empirical research in practical theology: The contribution of empirical theology by Johannes A. van der Ven, pp. 331-388, Brill, Leiden.

Van Huyssteen, J.W., 1997, Essays in postfoundational theology, W.M.B. Eerdmans, Grand Rapids.

Van Huyssteen, J.W., 1998, Duet or duel? Theology and science in a postmodern world, Trinity Press International, Harrisburg. 